\title{
Skaza na portrecie - postać Zofii Kossak w relacjach byłych więźniarek Birkenau ${ }^{1}$
}

...wprawdzie była w obozie, ale go nie ,przeżyła”...

Irena Mann

Opublikowana w 1946 roku książka Zofii Kossak $Z$ otchłani razem z Dymami nad Birkenau Seweryny Szmaglewskiej, Przeżyłam Oświęcim Krystyny Żywulskiej i opowiadaniami Tadeusza Borowskiego wpisuje się konstelację pierwszych literackich świadectw obozowych. Tekst od razu zyskał status wypowiedzi autorytetu moralnego, wyszedł bowiem spod pióra autorki niezwykle popularnych przed wojną powieści historycznych (w 1936 roku nagrodzonej Złotym Wawrzynem Polskiej Akademii Literatury), znanej działaczki katolickiej, a także ważniej członkini Polskiego Państwa Podziemnego. Z tego powodu druzgocąca krytyka utworu Kossak, którą na początku 1947 roku ogłosił młody poeta i debiutujący prozaik Tadeusz Borowski², wywołała nie tyle konsternację ówczesnych elit intelektualnych, ile otwarty atak na autora Pożegnania z Maria, przede wszystkim ze strony pisarzy i publicystów zaliczających się do nurtu katolickiego, wśród których postać założycielki Frontu Odrodzenia Polski cieszyła się szczególną estymą․

Na początek przypomnijmy zarzuty, jakie Borowski sformułował w odniesieniu do obozowego świadectwa Kossak - krótka rekapitulacja okaże się pomocna w zrozumieniu wspomnień byłych więźniarek, które podczas pobytu w Birkenau zetknęły się z autorką Krzyżowców. Zapis ich doświadczeń i spostrzeżeń w wielu miejscach współbrzmi z tonem artykułu Alicja w krainie czarów.

* Dr; Uniwersytet Warszawski; Instytut Kultury Polskiej, Zakład Historii Kultury; 00-927 Warszawa, ul. Krakowskie Przemieście 26/28; j.kowalska-leder@uw.edu.pl.

${ }^{1}$ Tekst powstał w ramach badań w projekcie ,Ślady Holokaustu w imaginarium kultury polskiej” finansowanym z programu Ministra Nauki i Szkolnictwa Wyższego pod nazwą „Narodowy Program Rozwoju Humanistyki" (nr 11H 12013481).

${ }^{2}$ T. Borowski, Alicja w krainie czarów, „Pokolenie” 1947, nr 1.

${ }^{3}$ Por. T. Drewnowski, Ucieczka z kamiennego świata. O Tadeuszu Borowskim, Państwowy Instytut Wydawniczy, Warszawa 1972; S. Buryła, Na antypodach tradycji literackiej. Wokót ,sprawy Borowskiego”, „Pamiętnik Literacki” 1998, z. 4; D. Kulesza, Dwie prawdy. Zofia Kossak i Tadeusz Borowski wobec obrazu wojny w polskiej prozie lat 1944-1948, Trans Humana, Białystok 2006. 
Pierwszy sformułowany zarzut dotyczy nierzetelnego przedstawienia realiów obozowych, tak jakby autorka w ogóle ich nie znała, co zaowocowało licznymi błędami topograficznymi, faktograficznymi i leksykalnymi. Po drugie, Borowski ma jej za złe kłamliwy opis postaw kobiet w Birkenau, wśród których Kossak idealizowała Polki, a szczególnie Polki-katoliczki, demonizując jednocześnie Niemki, zwłaszcza niemieckie więźniarki funkcyjne. Po trzecie, autor Alicji w krainie czarów uznał za fałszywe umieszczenie rzeczywistości obozowej w planie metafizycznym, a konkretnie - w odniesieniu do wartości chrześcijańskich, które - w świetle wspomnień Kossak - miały wyjść zwycięsko ze sprawdzianu, jakim był obóz. Ten osiowy wątek $Z$ otchłani Borowski określił wprost jako pseudomistycyzm. W jego artykule znajdziemy również zarzut natrętnego moralizatorstwa, które przejawia się między innymi nieustannym sugerowaniem czytelnikowi wrażeń, jakie powinny mu towarzyszyć podczas lektury. Borowski pisał o autorce $Z$ otchtani: ,stale czuje ona obecność czytelnika, co parę kartek odzywa się do niego, usiłuje podsunąć mu właściwe reakcje, uprzedzić jego niedowierzanie lub zdziwienie, objaśnić mu najprostsze fakty jakby czytelnik spadł z księżyca albo sześć lat był na emigracji”"4. Pod koniec artykułu Borowski podnosi kwestię fundamentalną $\mathrm{i}$ - jak się wydaje - nie do końca zrozumianą przez ówczesnych czytelników, a mianowicie definiuje etyczny wymiar świadectwa obozowego, który nie ma nic wspólnego z moralną kwalifikacją opisywanych w nim doświadczeń:

Porozumiejmy się: nikt nie złapie mnie na tym, że zarzucam autorce $Z$ otchłani, iż przeszła obóz w sposób nieetyczny. Mam jej tylko za złe - i to bardzo za złe - że nie miała odwagi wprowadzić do opowieści i osądzić siebie samą. [...] Uważam dalej, że nie wolno o Oświęcimiu pisać bezosobowo. Pierwszym obowiązkiem oświęcimiaków jest zdać sprawę z tego, co to obóz - tak, ale niech nie zapominają, że czytelnik, który czyta ich relacje i przebrnie wreszcie przez wszystkie okropności, nieodmiennie zapyta: no, dobrze, a jak to się stało, że właśnie pan(i) przeżył(a)? Nie ma co staczać z sobą polemiki, dowodzić, że rozsądnie było udzielać z paczek w miarę lub spełniać jakieś tam chrześcijańskie posługi. Nie ma co: opowiedzcie wreszcie, jak kupowaliście miejsca w szpitalu, na dobrych komandach, jak spychaliście do komina muzułmanów, jak kupowaliście kobiety i mężczyzn, co robiliście w Unterkunftach, Kanadach, Krankenbaumach, na obozie cygańskim, opowiedzcie to i jeszcze wiele drobnych rzeczy, opowiedzcie o dniu codziennym obozu, o organizacji, o hierarchii strachu, o samotności każdego człowieka. Ale piszcie, że właśnie wyście to robili! Że cząstka ponurej sławy Oświęcimia i wam się należy! Może nie, co? ${ }^{5}$

\footnotetext{
${ }^{4}$ T. Borowski, dz. cyt., s. 9 .

5 Tamże.
} 
Książka Zofii Kossak jest skrajnie odmienna od opowiadań oświęcimskich, w których Borowski z premedytacją i, można powiedzieć, bez cienia litości dla samego siebie zrealizował własny projekt świadectwa obozowego. W centrum tej realizacji sytuuje się narracja personalna spleciona z pierwszoosobową, która prowadzona jest z perspektywy młodego więźnia noszącego imię Tadek i - co w tekście sugerowane - mającego wytatuowany na przedramieniu numer obozowy Borowskiego. Tymczasem $Z$ otchtani najbliżej jest do auktoralnego modelu narracji, który charakteryzuje się tym, że narrator - tak jak czytelnik - znajduje się poza światem przedstawionym, eksponując jednocześnie szerokie kompetencje w kwestiach, o których opowiada ${ }^{6}$. Pośredniczy między czytelnikiem a światem przedstawionym, w którym sam nie partycypuje wcale lub czyni to w niewielkim zakresie. Z książki Kossak nie poznamy więc okoliczności jej aresztowania, nie dowiemy się, jak długo trwał jej pobyt w KL Auschwitz-Birkenau, a tym bardziej nie otrzymamy odpowiedzi na pytanie: ,jak to się stało, że właśnie pani przeżyła?”.

Dariuszowi Kuleszy na postawie wielu źródeł udało się zrekonstruować kolejne etapy pobytu pisarki w obozie Birkenau, gdzie przebywała od października 1943 roku do kwietnia 1944. Pierwszy miesiąc Kossak spędziła na tak zwanej kwarantannie, a gdy pod koniec grudnia zachorowała na tyfus brzuszny, znalazła się na rewirze, czyli w szpitalu obozowym. Jej rekonwalescencja trwała nieprzerwanie do dnia, w którym została wywieziona z obozu, by trafić na Pawiak, skąd udało się ją uwolnić dzięki staraniom Delegatury Rządu pod koniec lipca 1944 roku. Jak wykazała szeroka kwerenda autora Dwóch prawd, w opublikowanych wspomnieniach i relacjach, w których mowa o działalności i postawie Zofii Kossak podczas wojny, dominuje ton hagiograficzny. Jej współpracownicy z podziemia i inne osoby, które miały z nią styczność, wyznają, że nawet po latach pozostają nią urzeczeni. Zofia Kossak imponowała odwagą i prawością, porywała charyzmą. Zapisała się w pamięci wielu jako osoba niesłychanie wytrzymała zarówno psychicznie, jak i fizycznie, a także wrażliwa na potrzeby otaczających ją ludzi, opiekuńcza, wspierająca, dodająca otuchy i wiary. W świadectwach budujących legendę Zofii Kossak znajdziemy wiele emocjonalnych, a zarazem afirmatywnych epitetów: ,świetlana postać, najszlachetniejszy płomień, natchnienie konspiracji, najdzielniejsza z dzielnych, płonąca odwagą i wolą twórczą, kobieta-żołnierz, bohaterska «Weronika», nieustraszona «Ciotka», nasz skarb narodowy"».

\footnotetext{
${ }^{6}$ Por. F. Stanzel, Typowe formy powieści, przekł. R. Handke, w: Teorie form narracyjnych w niemieckim kręgu językowym, red. R. Handke, Wydawnictwo Literackie, Kraków 1980, s. 243-287.

${ }^{7}$ Por. Zofia Kossak, red. M. Pałaszewska, Muzeum Niepodległości w Warszawie, Fundacja Archiwum Polski Podziemnej 1939-1956, Warszawa 1992; M. Pałaszewska, Zofia Kossak w latach II wojny światowej, „Niepodległość i Pamięć” 1995, nr 3; M. Komar, W. Bartoszewski, Skąd pan jest? Wywiad rzeka, Świat Książki, Warszawa 2006.

${ }^{8}$ Zob. D. Kulesza, dz. cyt., s. 27.
} 
W archiwum Państwowego Muzeum Auschwitz-Birkenau zachowały się niepublikowane dotąd relacje byłych więźniarek obozu, które pośród wielu wątków i postaci przywołują również Zofię Kossak9 . Autorki większości tych wspomnień, spisywanych od początku lat 60. do końca lat 90., podczas pobytu w obozie zetknęły się z Kossak w bloku 17, na tak zwanym rewirze, czyli w szpitalu, w którym założycielka FOP spędziła ponad połowę z siedmiu miesięcy uwięzienia w Birkenau ${ }^{10}$. W ich świadectwach powtarza się wątek izolacji Zofii Kossak od reszty obozu i jej bardzo ograniczony wgląd w typowe warunki życia przeciętnego więźnia lagru. Była to izolacja spotęgowana, ponieważ po pierwsze - rewir stanowił stosunkowo bezpieczną przestrzeń odseparowaną od reszty obozu, a po drugie - popularna pisarka, działaczka katolicka i niekwestionowany autorytet polskiego podziemia otoczona została szczególną opieką przez obozowy ruch oporu, w wyniku czego jej warunki bytowe były nieporównywalnie lepsze od położenia, w jakim znalazły się inne więźniarki, nawet te przebywające w szpitalu. Janina Wojnar-Sujecka, która zetknęła się z Zofią Kossak właśnie w bloku szpitalnym, w relacji złożonej w połowie lat 90. podkreśla jego szczególne położenie w przestrzeni obozu: „Niewiele mogę powiedzieć o rzeczach, które miały miejsce poza obrębem szpitala czy nawet bloku 17. Żyłyśmy tam do pewnego stopnia w izolacji i rzadko dochodziły nas wieści z zewnątrz"11. $\mathrm{Na}$ ten sam aspekt, tyle że w odniesieniu do bloku kwarantanny, zwraca uwagę Eugenia Kurzelowa, która miała styczność z Zofią Kossak podczas pierwszego miesiąca jej pobytu w obozie. I tym razem mowa jest o swoistej enklawie na terenie Birkenau: „Na bloku kwarantanny nie odbywały się nawet apele - tu był odpoczynek"12 - wspomina Kurzelowa.

Jak widać, większość pobytu Zofii Kossak w obozie upłynęła w izolacji od tego, co uznać można za typowe aspekty doświadczenia lagrowego, których opis pojawia się już we wczesnych świadectwach byłych więźniów. Mowa w nich o przybywających do obozu transportach, o dymiących kominach, o przerażającym wyglądzie muzułmanów, o pracy komand zewnętrznych, a także o surowych karach wymierzanych więźniom czy eksperymentach pseudomedycznych, których padali ofiarami. Na niektóre z tych wątków natkniemy się podczas lektury $Z$ otchtani. $Z$ całą pewnością nie zostały one wywiedzione z naocznego doświadczenia Zofii Kossak, lecz z zasłyszanych przez nią opowieści. Co jednak ważne, pisarka nie tylko przełożyła je na język literatury, ale przede wszystkim dogłębnie zinterpretowała, umieściła w ramach wytyczonych przez granice własnego świa-

\footnotetext{
${ }^{9}$ Trudno całkowicie wykluczyć, że jakieś fragmenty przywoływanych przeze mnie relacji ukazały się drukiem. Z pewnością nie weszły jednak do kanonu świadectw dotyczących uwięzienia Zofii Kossak w KL Auschwitz-Birkenau.

${ }^{10}$ Por. D. Kulesza, dz. cyt., s. 25.

${ }^{11}$ J. Wojnar-Sujecka, „Oświadczenia” 1995, t. 130.

12 E. Kurzelowa, „Oświadczenia” 1963, t. 36.
} 
topoglądu, wyobraźni i wrażliwości religijnej. W efekcie - jak zauważa Dariusz Kulesza - Z otchłani odczytywać należy, w przeciwieństwie na przykład do opowiadan Borowskiego, jako świadectwo wiary, a nie świadectwo doświadczenia obozowego $^{13}$. Potwierdzenie tej konkluzji znaleźć można w relacji Ireny Mann, która zetknęła się z Kossak w szpitalu obozowym. Wspomina ona, że już wcześniej obecność pisarki w Birkenau stała się wśród więźniów publiczną tajemnicą, mimo że zaaresztowana z fałszywymi dokumentami jako Zofia Śliwińska, nie została rozpoznana przez administrację obozu. Dla więźniarek przebywających na rewirze kontakt z Zofią Kossak był bardzo ważnym doświadczeniem, wiązały z nim bowiem nadzieję, że świat - dzięki talentowi wybitnej pisarki - pozna kiedyś prawdę o tym, czym był Oświęcim.

Ponieważ doceniałyśmy jej ogromny talent, więc my „stare” więźniarki starałyśmy się jej opowiedzieć, jak to było na początku. Ona zawsze jednak powtarzała - dziewczęta, to niemożliwe, żeby było gorzej niż jest teraz. Myśmy mówiły - Pani Zofio, jeśli Pani nam nie wierzy, to kto nam uwierzy? Teraz jest woda, jest światło, są paczki. Lagerstrasse jest wybrukowana, a dawniej grzęzłyśmy na niej w błocie, można zdobyć jakieś rzeczy z Effektenkammer. W porównaniu z 1942 rokiem był to postęp, jak na obóz koncentracyjny. Pani Zofia nie mogła jednak mimo wszystko uwierzyć. Zresztą zaopiekowano się nią od samego początku, ona nawet nie była wcale głodna, nie wychodziła do pracy i wprawdzie była w obozie, ale go nie „przeżyła” tak jak inne, bo od samego początku była otoczona kokonem. Natomiast Szmaglewska naprawdę „przeżyła” obóz. Pracowała w różnych komandach. I jeśli można powiedzieć, że książka Szmaglewskiej Dymy nad Birkenau jest dokumentem, tam nie ma nic przerysowanego, to książka $Z$ otchlani jest - według nas „starych” więźniarek - mdła. Również książka Krystyny Żywulskiej jest dobra. Natomiast Kossak-Szczucka nas zawiodła, a myśmy tak liczyły, że napisze dobrą książkę o obozie, tak w nią wierzyłyśmy. Ja byłam jedną z tych, które chciały przekazać jej całą prawdę o tym, co zastałyśmy po przybyciu do obozu. Jak obóz i życie wyglądały na początku, a ona wciąż powtarzała: to niemożliwe ${ }^{14}$.

Opisana przez Irenę Mann reakcja pisarki na opowieści współwięźniarek przywodzi skojarzenie ze starym buddyjskim przysłowiem, obrazowanym za pomocą znanej figurki trzech małpek. Wizualizują one następującą sentencję: kto nie widzi zła, nie słyszy zła, nie mówi o złu, tym samym się przed nim chroni. Z przytoczonej relacji wyłania się obraz właśnie takiego gestu Zofii Kossak, która zakrywa uszy, aby nie słuchać o niewyobrażalnym koszmarze. Można to rozumieć jako formę obrony skrystalizowanej wizji świata, z jaką pisarka trafiła do

${ }^{13}$ D. Kulesza, dz. cyt., s. 76-79.

${ }^{14}$ I. Mann, „Oświadczenia” 1998, t. 143. 
obozu. Przypomnijmy, że miała wówczas ponad pięćdziesiąt lat, zdążyła owdowieć i wyjść powtórnie za mąż, urodzić czworo dzieci, a jedno z nich pochować. Dysponowała ogromnym doświadczeniem prozatorskim, miała także za sobą wiele lat zaangażowania w działalność społeczną, a - co najważniejsze - jej całe dotychczasowe życie wspierało się na stabilnym fundamencie wiary katolickiej. Jak zauważa Dariusz Kulesza,

Zofia Kossak broniła się przed obozem (broniła przed nim swoich czytelników), nie pozwalając sobie (a w konsekwencji i swoim czytelnikom) dostrzec go. [...] nie napisała o tym, jak można przez obóz przejść, bo w ogóle do niego nie weszła - nie uległa mu, nie pozwoliła mu zaistniećc ${ }^{15}$.

Zupełnie inaczej rzecz wyglądała w przypadku Tadeusza Borowskiego, który trafił do obozu, skończywszy zaledwie dwadzieścia lat. Na sumę jego najważniejszych doświadczeń życiowych składały się wówczas: pierwsza poważna miłość, tomik wierszy i studia na konspiracyjnej polonistyce. Jak słusznie podkreśla autor Dwóch prawd, ,proza obozowa Borowskiego (inaczej niż $Z$ otchłani) nie powstała $\mathrm{w}$ rezultacie podporządkowania rzeczywistości koncentracyjnej temu, co decydowało o przedobozowym życiu Vorarbeitera Tadka"16. Jego percepcja obozu nie była zdeterminowana wykrystalizowanymi wcześniej kategoriami, przeciwnie - poznawszy reguły Auschwitz-Birkenau, rzutował je na świat poza drutami.

Można powiedzieć, że - w przeciwieństwie do Zofii Kossak - Borowski, przebywając w obozie, nieustannie miał szeroko otwarte oczy i wyostrzony słuch, którym chłonął opowieści o tym, czego nie mógł zobaczyć. W swoich opowiadaniach ukazuje między innymi dynamikę przemian, jakie zaszyły od momentu utworzenia obozu do okresu znanego Borowskiemu z autopsji. „Wiadomo, że Oświęcim i Birkenau szły od złego do dobrego"17 - tymi słowami w opowiadaniu Ludzie, którzy szli lapidarnie ujmuje istotę zmian w życiu obozowym, na które bezskutecznie próbowały zwrócić uwagę Zofii Kossak „stare” więźniarki. Następnie Borowski wyjaśnia, że przeobrażenia polegały między innymi na tym, iż więźniowie byli rzadziej bici i zabijani podczas pracy w komandach, spanie na podłodze skończyło się wraz ze zbudowaniem prycz, skróciły się apele, Polacy zaczęli otrzymywać paczki, a nawet pozwolono więźniom nosić cywilne ubrania. Borowski zaznacza przy tym, że ukazana przez niego ewolucja nie obejmuje całości obozu. Akcja opowiadania Ludzie, którzy szli rozgrywa się wiosną 1944 roku, a więc w okresie tak zwanych transportów węgierskich, o czym autor

${ }^{15}$ D. Kulesza, dz. cyt., s. 78.

16 Tamże, s. 79.

${ }^{17}$ T. Borowski, Ludzie, którzy szli, w: tenże, Wspomnienia. Wiersze. Opowiadania, Państwowy Instytut Wydawniczy, Warszawa 1974, s. 136. 
nie informuje nas wprost. Zaznacza jednak, że kobiety, którym udało się wyjść cało z selekcji, trafiały do niezagospodarowanej jeszcze części Birkenau:

Na Perskim Rynku czas cofnął się wstecz. Oglądaliśmy znowu Oświęcim z czterdziestego roku. Kobiety pożądliwie chłeptały zupę, której u nas na blokach nikt nie jadł. Śmierdziały potem i krwią kobiecą. Od godziny piątej rano stały na apelu. Zanim je policzono była prawie dziewiąta. Wtedy dostawały zimną kawę ${ }^{18}$.

Borowski bardzo wyraźnie zaznacza również przepaść cywilizacyjną, jaka dzieliła dwie części kompleksu KL Auschwitz-Birkenau. „Ludzie są w Oświęcimiu zakochani, z dumą mówią: «U nas, w Auschwitzu...»"19 - to jedno z tych zdań, które wtrącają w absolutną konsternację czytelnika przywykłego do narracji martyrologicznej i przewidującego, że z nią właśnie będzie miał do czynienia, biorąc do rąk tom opowiadań autora ocalałego z lagru. Jednak powoli, zagłębiając się w lekturę, zyskuje szansę zrozumienia powodów „zakochania się” więźniów w Auschwitz oraz ich „dumy” połączonej z pogardą i politowaniem, gdy spoglądają na nieszczęśników z Birkenau, gdzie w porównaniu z obozem macierzystym warunki były prymitywne, a przede wszystkim - gdzie pełną parą pracowała machina Zagłady.

W książce $Z$ otchtani próżno szukać informacji ukazujących dynamikę przemian obozu Auschwitz-Birkenau oraz jego wewnętrzne zróżnicowanie, często zaskakujące sprzecznościami i nie znajdujące łatwego uzasadnienia funkcjonalnego. Brak głębszej znajomości realiów obnażają już pierwsze słowa wstępu Zofii Kossak, z których czytelnik dowiaduje się, że Birkenau to lager kobiecy, Auschwitz zaś - męski20. Jak wynika z relacji Ireny Mann, to przede wszystkim powierzchowny opis życia obozowego zadecydował o tym, że byłe więźniarki odebrały $Z$ otchłani jako książkę ,mdłą", w przeciwieństwie do wspomnień Szmaglewskiej czy Żywulskiej. Co prawda nie oceniły jej równie bezlitośnie jak Borowski jako „złą i fałszywą, a przede wszystkim beznadziejnie słabą literacko"21, to jednak ich opinię, przywołaną w cytowanej relacji, traktować można jako swoisty przypis do Alicji w krainie czarów, potwierdzający sformułowane tam zarzuty.

O ile Borowski zastrzegał wyraźnie, że jego krytyka dotyczy wyłącznie książki (,,nikt nie złapie mnie na tym, że zarzucam autorce $Z$ otchłani, iż przeszła obóz w sposób nieetyczny") ${ }^{22}$, o tyle niektóre z byłych więźniarek, składając relacje do muzealnego archiwum, wyrażały się negatywnie bądź z wyraźną rezerwą na temat sposobu funkcjonowania Zofii Kossak w obozie. Przywoływana już

\footnotetext{
${ }^{18}$ Tamże, s. 137.

19 T. Borowski, Unas, w Auschwitzu, w: tenże, Wspomnienia..., s. 91.

${ }^{20}$ Z. Kossak, Z otchtani, Książka i Wiedza, Warszawa 2004, s. 5.

${ }^{21}$ T. Borowski, Alicja w krainie czarów, s. 9.

22 Tamże.
} 
Janina Wojnar-Sujecka, która przebywała z pisarką w bloku szpitalnym, ciepło wspomina słynną położną z Birkenau Stanisławę Leszczyńską, a także Sewerynę Szmaglewską, między innymi za to, że rozdawała wśród pacjentek przysyłane przez swoich bliskich paczki żywnościowe.

Nie najlepiej natomiast zapisała się w mojej pamięci Zofia Kossak-Szczucka. Moim zdaniem była zbyt zarozumiała, a jej zachowanie nosiło znamiona samolubstwa i egoizmu. Zdołała zgromadzić wokół siebie grono koleżanek, które traktowały ją jako osobę wysoce nieprzeciętną i stale obsypywały pochlebstwami. Miała na swojej koi czyste, białe prześcieradło i w ogóle zapewniano jej cieplarniane warunki ${ }^{23}$.

Podobny ton pobrzmiewa w relacji Marii Oyrzyńskiej z 1982 roku. Opisując warunki życia w bloku szpitalnym, wspomina o przejmującym chłodzie, któremu z narażeniem życia próbowały zaradzić więźniarki, od czasu do czasu „organizując" nocą trochę opału.

Kiedy na naszym bloku przebywała Zofia Kossak-Szczucka dla niej najczęściej palono w tym piecu i zajmowano garnkami miejsca na ruszcie, zsuwając garnki innych więźniarek, bo przez cały dzień dla pani Zofii grzała się albo woda do mycia, albo woda do termoforu, żeby mogła nim grzać stopy, albo zupa, albo ziemniaki, albo gotowano kluski z ziemniaków, albo pieczono placki ziemniaczane ${ }^{24}$.

Relacje Janiny Wojnar-Sujeckiej i Marii Oyrzyńskiej nie tylko potwierdzają fakt, że Zofia Kossak jako ważna postać Polski Podziemnej znalazła się pod opieką obozowego ruchu oporu, który starał się uchronić ją od doświadczeń przeciętnego więźnia Auschwitz-Birkenau. Wskazują również na to, że w oczach przynajmniej niektórych więźniarek, sposób, w jaki pisarka przyjmowała pomoc podziemia, był nieetyczny - podszyty egoizmem i obojętnością na cierpienia innych. Na te odczucia pewien wpływ mogły mieć oczekiwania żywione wobec osoby znanej z głoszenia wartości chrześcijańskich, takich jak miłosierdzie, wrażliwość na cierpienie słabszych i w końcu - gotowość złożenia ofiary z samego siebie w geście naśladownictwa Chrystusa. Wartości te kształtują nie tylko przedwojenny i okupacyjny wzorzec pisarstwa Zofii Kossak, ale również stanowią religijno-etyczny fundament, na którym wspiera się jej świadectwo obozowe. Książka $Z$ otchłani, pisana z myślą o wielkiej akcji wychowawczej dla powojennego świata, miała być dowodem na to, że wartości chrześcijańskie wyszły zwycięsko ze sprawdzianu, jakiemu poddano je w okrutnych i nieludzkich warunkach panujących w Birkenau. Nie ma podstaw, by twierdzić, że przesłanie

23 J. Wojnar-Sujecka, dz. cyt.

${ }^{24}$ M. Oyrzyńska, „Oświadczenia” 1982, t. 98. 
to zostało sformułowane w sposób nieszczery. Zwielokrotniona ochrona, jakiej Kossak poddana była w lagrze (z jednej strony opieka ruchu oporu, a z drugiej - jej własna samoobrona przed poznaniem realiów obozowych), uniemożliwiła jej rozpoznanie tego, że sama stała się elementem w systemie fałszywych moralnie alternatyw. Tymczasem, jak zauważył Andrzej Werner, taka właśnie diagnoza stanowi fundament opowiadań oświęcimskich Borowskiego ${ }^{25}$. Ukazują one obóz jako układ alternatyw, które są dlatego fałszywe, że bez względu na wybór zawsze pozostają zwrócone przeciwko życiu - własnemu lub cudzemu. Wynikało to przede wszystkim z faktu, że obóz stanowił zamknięty system dystrybucji żywności, leków i innych zasobów niezbędnych do przeżycia. Zofia Kossak nie rozumiała i - jak sądzić można - nie chciała zrozumieć, że czyste prześcieradło, ciepła zupa, termofor czy woda podgrzewana dla niej na piecu, oznaczają zmniejszenie szansy na przeżycie innej więźniarki z bloku szpitalnego.

Wśród zgromadzonych w archiwum Muzeum Auschwitz-Birkenau relacji byłych współwięźniarek Zofii Kossak znajdziemy i takie, które harmonijnie współbrzmią z hagiograficznym tonem publikacji poświęconych „,najdzielniejszej z dzielnych" polskiego podziemia. Pisarka ukazywana jest w nich jako animatorka życia kulturalnego, a także inicjatorka praktyk religijnych niosących otuchę innym więźniarkom. Przywoływana już Eugenia Kurzelowa w swoim wspomnieniu z 1963 roku wraca do początków pobytu Kossak w obozie: „Na bloku kwarantanny było nas około trzydziestu kobiet. Tu spotkałam Kossak-Szczucką, która pod przybranym nazwiskiem Zofia Śliwińska podtrzymywała więźniarki na duchu, opowiadając nam historyczne wydarzenia i legendy" ${ }^{\prime 26}$. Podobny wątek znajdziemy w relacji złożonej w 1970 roku przez Stanisławę Rachwałową, przed uwięzieniem - wywiadowczynię Związku Walki Zbrojnej, a w obozie - działaczkę ruchu oporu, która otrzymała polecenie zaopiekowania się nie tylko Zofią Kossak, lecz również Celiną Mikołajczykową. Wspomina ona, że konspiracja obozowa przesłała do Warszawy zapytanie o zgodę na zorganizowanie ucieczki Kossak. Odpowiedź była negatywna przede wszystkim dlatego, że jej zniknięcie z obozu naraziłoby na śmierć inne więźniarki, gdyby zastosowana została odpowiedzialność zbiorowa. Był jednak jeszcze dodatkowy powód niepodejmowania ryzyka ucieczki: „Poza tym Zofia Kossak nazywana Ciocią Zosią była potrzebna w obozie. Umiała podtrzymywać na duchu inne więźniarki. W 1943 roku urządziła gwiazdkę w obozie, w której uczestniczyło około 80 osób. Przemawiała do nas pięknie, śpiewałyśmy kolędy"27. Relacja Rachwałowej mieści się w tym samym nurcie, co wydane drukiem wspomnienie Marii Przełęckiej, w którym przykuwa uwagę nieustanne rozmodlenie pisarki: „, każdej możliwie wolnej

${ }^{25}$ A. Werner, Zwyczajna apokalipsa. Tadeusz Borowski i jego wizja świata obozów, Czytelnik, Warszawa 1971.

${ }^{26}$ E. Kurzelowa, dz. cyt.

${ }^{27}$ S. Rachwałowa, „Oświadczenia” 1970, t. 69. 
chwili modliła się w cichości, a w niedzielę «odmawiała» po polsku całą mszę św. półgłosem, jeśli się udało skupić choćby małej grupie. Niezapomniane chwile"28. Zofia Kossak jako animatorka życia religijnego w obozie, regularnie praktykująca także cichą, indywidualną modlitwę, nie wśród wszystkich więźniarek budziła podziw i entuzjazm. Wspomnienie o tym znajdziemy w relacji złożonej w 1980 roku przez Marię Slisz-Oyrzyńską, która - co ważne - opisuje nie tylko swoje własne odczucia, lecz także reakcje szerszego grona kobiet przebywających na rewirze: „Zofia Kossak-Szczucka (Śliwińska), leżąc na naszym bloku 17, modliła się przez cały dzień. Bez przerwy, aż nas to bardzo denerwowało. Modliła się półgłosem. Najwięcej na różańcu (jeszcze dziś widzę ten niebieski różaniec)"29. Potwierdzenie tego, że praktyki religijne mogły być odbierane przez otoczenie jako rodzaj uciążliwej dewocji, znajdziemy w opowiadaniu Borowskiego Prosze państwa do gazu. Jedna ze scen rozgrywa się w przepełnionym baraku, gdzie na dolnych pryczach stłoczeni są najbardziej chorzy i wygłodniali więźniowie, a wśród nich rabin, który, nakrywszy głowę kawałkiem szmaty, czyta hebrajski modlitewnik, „zawodząc głośno i monotonnie" ${ }^{30}$. Narrator reaguje na to z wyraźną irytacją: „Może by się tak zdało go uspokoić? Drze się, jakby Boga za nogi złapał" ${ }^{31}$. Relacja Marii Slisz-Oyrzyńskiej wskazuje na to, że podobne uczucia mogły wywoływać również modły Zofii Kossak, które nie wszystkich podnosiły na duchu.

Przywołane w artykule relacje byłych współwięźniarek Zofii Kossak $\mathrm{w}$ znacznej mierze odbiegają od hagiograficznego tonu dominującego w poświęconych jej wspomnieniach. Z pewnością można je uznać za głosy wspierające krytyczne stanowisko Borowskiego, jednak największą ich wartością jest przybliżenie nas do odpowiedzi na zadane przez niego pytanie, w jaki sposób Zofii Kossak udało się przetrwać obóz. O tym, że była pod opieką ruchu oporu, wiadomo z innych źródeł, jednak więźniarki odsłaniają praktyczny wymiar tej pomocy oraz jej skutki dla kobiet z otoczenia pisarki. Pokazują także, w jaki sposób ona sama broniła się przed „zakażeniem” lagrem, a jednocześnie uświadamiają, że nawet duchowa samoobrona mogła nieść negatywne konsekwencje dla innych uwięzionych w systemie fałszywych moralnie alternatyw.

\section{Bibliografia}

Źródła niepublikowane ze zbiorów Archiwum Państwowego Muzeum Auschwitz-Birkenau: Kurzelowa Eugenia, „Oświadczenia” 1963, t. 36.

${ }^{28}$ M. Przełęcka, Zofia Kossak jaka pamiętam (wspomnienia łączniczki), w: Zofia Kossak, s. 45.

${ }^{29}$ M. Slisz-Oyrzyńska, „Oświadczenia” 1980, t. 94. Cytowaną wcześniej relację z 1982 roku autorka podpisała nazwiskiem jednoczłonowym. Zob. M. Oyrzyńska, „Oświadczenia” 1982, t. 98.

${ }^{30}$ T. Borowski, Proszę państwa do gazu, w: tenże, Wspomnienia..., s. 172.

${ }^{31}$ Tamże. 
Mann Irena, „Oświadczenia” 1998, t. 143.

Oyrzyńska Maria, „Oświadczenia” 1982, t. 98.

Rachwałowa Stanisława, „Oświadczenia” 1970, t. 69.

Slisz-Oyrzyńska Maria, „Oświadczenia” 1980, t. 94.

Wojnar-Sujecka Janina, „Oświadczenia” 1995, t. 130.

Źródła publikowane:

Borowski Tadeusz, Alicja w krainie czarów, „Pokolenie” 1947, nr 1, s. 9.

Borowski Tadeusz, Wspomnienia. Wiersze. Opowiadania, Państwowy Instytut Wydawniczy, Warszawa 1974.

Buryła Sławomir, Na antypodach tradycji literackiej. Wokół „,sprawy Borowskiego”, „Pamiętnik Literacki" 1998, z. 4, s. 99-123.

Drewnowski Tadeusz, Ucieczka z kamiennego świata. O Tadeuszu Borowskim, Państwowy Instytut Wydawniczy, Warszawa 1972.

Komar Michał, Bartoszewski Władysław, Skąd pan jest? Wywiad rzeka, Świat Książki, Warszawa 2006.

Kossak Zofia, Z otchtani, Książka i Wiedza, Warszawa 2004.

Kulesza Dariusz, Dwie prawdy. Zofia Kossak i Tadeusz Borowski wobec obrazu wojny w polskiej prozie lat 1944-1948, Trans Humana, Białystok 2006.

Pałaszewska Mirosława, Zofia Kossak w latach II wojny światowej, „Niepodległość i Pamięć” 1995, nr 3, s. 49-94.

Stanzel Franz, Typowe formy powieści, przekł. Ryszard Handke, w: Teorie form narracyjnych w niemieckim kręgu językowym, red. Ryszard Handke, Wydawnictwo Literackie, Kraków 1980, s. 237-297.

Werner Andrzej, Zwyczajna apokalipsa. Tadeusz Borowski i jego wizja świata obozów, Czytelnik, Warszawa 1971.

Zofia Kossak, red. Mirosława Pałaszewska, Muzeum Niepodległości w Warszawie, Fundacja Archiwum Polski Podziemnej 1939-1956, Warszawa 1992.

Justyna Kowalska-Leder

\section{Blemish on the portrait - the character of Zofia Kossak presented in the postwar accounts by female prisoners}

\section{Summary}

This article analyzes how the postwar accounts by female prisoners of Birkenau presented the character of Zofia Kossak, the famous writer and the activist of the Polish Underground State. The accounts are held today in the Archives of the Auschwitz-Birkenau State Museum and were hitherto unpublished. They shows Zofia Kossak in an unheroic way, contrary to the published testimonies of her camp experience. The accounts are reminiscent of the famous article Alice's Adventures in Wonderland published by Tadeusz Borowski in 1947.

Keywords: KL Auschwitz-Birkenau; Zofia Kossak; postwar accounts by female prisoners; Tadeusz Borowski 